\title{
Do Theorists of History Have a Theory of History? Reflections on a Non-Discipline
}

\author{
Os teóricos da História possuem uma Teoria da História? \\ Reflexōes sobre uma nāo disciplina
}

\section{ABSTRACT}

This brief article is a discussion-starter on the question of the role and use of theories and philosophies of history. In the last few decades, theories of history typically intended to transform the practice of historical studies through a straightforward application of their insights. Contrary to this, I argue that they either bring about particular historiographical innovations in terms of methodology but leave the entirety of historical studies intact or change the way we think about the entirety of historical studies merely by describing and explaining it in fresh and novel ways, without the need (and possibility) of application. In the former case, theories appear as internal to historical studies. In the latter case, they appear as theories about history, and such theories are no longer limited to study history understood as historical writing. In reflecting on the historical condition of the ever-changing world, they foster a more fruitful cooperative relationship with the discipline of history. Discussing the scope and use of such theories of history is inevitable today when a younger generation sets out to theorize history against the backdrop of the experiential horizon of their own times.

\section{KEYWORDS}

Theory of History; Philosophy of History, Historiography.

\author{
Zoltán Boldizsár Simon \\ https://orcid.org/0000-0001-8763-7415 (D)
}

\section{RESUMO}

Este breve artigo faz uma discussão inicial sobre o papel e o uso de teorias e filosofias da história. Nas últimas décadas, as teorias da história em geral pretenderam transformar a prática dos estudos históricos por meio de uma aplicação direta de seus insights. Em vez disso, argumento que essas teorias ou trazem inovações historiográficas particulares em termos de metodologia, mas deixam a totalidade dos estudos históricos intactos, ou transformam a maneira como nós pensamos sobre a totalidade dos estudos históricos apenas descrevendo e explicando-os através de formas novas e inovadoras, sem a necessidade (e possibilidade) de aplicação. No primeiro caso, as teorias parecem internas aos estudos históricos. No último, elas parecem como teorias sobre a história, e tais teorias não estão mais limitadas a estudar a história entendida como escrita da história. Ao refletir sobre a condição histórica do mundo em constante mudança, elas promovem uma relação cooperativa mais frutífera com a disciplina da história. Discutir o escopo e o uso de tais teorias da história é inevitável hoje, quando uma geração mais jovem se propõe a teorizar a história contra o pano de fundo do horizonte experiencial de seus próprios tempos.

\section{PALAVRAS-CHAVE}

Teoria da História; Filosofia da História; Historiografia. 
Are you fascinated by questions of historical knowledge? Are you engaged in mapping the narrative strategies of history? Or do you rather ask yourself lately how the Anthropocene and visions of a posthuman future might transform whatever we think history is? Perhaps you find it more important to explore the ways in which the category of gender pervades historical practice. Or maybe you just give a pause to questions concerning historical studies and venture into theorizing something like a historical process. Perhaps you are fascinated by discourses of memory and trauma and by the question of how they relate to history. Or do you have a methodological proposal instead? Do you theorize global history, environmental history, or postcolonial history? Are you a conceptual historian? Do you plan to announce a "turn" in historical studies or to contribute to one? Maybe you did that already.

If you are and if you do or did, then most likely you think of yourself the same way as most likely your colleagues think of you, namely, as someone being engaged in what is commonly called historical theory. Or theory of history. Or philosophy of history. Or, all this taken together: the theory and philosophy of history. This is the intellectual activity I am usually engaged in too, and this is the activity that puzzles me a lot. Not only when I actually pursue it, but also when I try to explain what it is what I actually do while pursuing it in the first decades of the $21^{\text {st }}$ century.

The difficulties begin right away with naming the activity itself as a field of study. The three most popular alternatives are, as indicated above, historical theory, theory of history, and philosophy of history. Yet it would be mistaken to argue that these three terms are equivalent in their current usage. They seem to overlap in many ways, but they also differ in many others, most apparently regarding their scope in terms of inclusivity and exclusivity. In reviewing the options, Herman Paul opts for "historical theory" in his introductory book for undergraduate students precisely for inclusiveness reasons (PAUL 2015). In Paul's view, the inclusivity largely stems from the possibility to overcome a view of "philosophy of history" that 
sharply distinguishes between its "speculative" and "critical" (WALSH 1960) or "substantive" and "analytical" versions (DANTO 1985). And Paul, I think, makes a call that suits the purpose of inclusivity on multiple levels. For the distinctions were introduced by analytic philosophers in the postwar decades with the intention to legitimize a study of historical knowledge and delegitimize speculating about anything like a historical process. They are not merely about what constitutes "proper" philosophy, but also about what is the "proper" sense of the word history. Whereas old speculative and substantive philosophies of history were engaged in mapping history understood as the unitary course of human affairs, a legitimate critical or analytical philosophy of history would study history understood as historical studies (or, in a wider sense, any practices that claim to produce historical knowledge, including old philosophies of history). Overcoming the distinction by "historical theory" would then imply at least a renegotiation of the relationship between the two senses of the word "history".

Yet things are a bit more complicated than this. For what seems to be a desirable term for Paul because of its integrative potential might look desirable for others precisely because of its potential for exclusivity. The latter potentiality is what informs Nancy Partner's take on the issue as the coeditor of The SAGE Handbook of Historical Theory. Partner distinguishes between "philosophy of history" and "theory" considering the different senses of history, claiming that whereas the former deals with the historical process, the restricted sense of "historical theory" should concern only matters of the discipline of history (PARTNER 2013, p. 2). She thereby posits a divide not only between the different senses of history, but also between "philosophy" and "theory" (although the distinction suspiciously resembles the distinction of analytic philosophers, with "theory" standing for the legitimate and "philosophy" standing for the illegitimate).

The situation arising out of Partner's and Paul's stances is rather uncomfortable. By mentioning only two different takes 
on a single term - "historical theory" - multiple divisions already come to light: between different understandings of "philosophy of history", between different senses of "history" as historical studies or as the course of human affairs, between "philosophy" and "theory". Reviewing even more variations and eventually solving the naming problem, however, is not the purpose of this essay (see SIMON; KUUKKANEN 2015). Instead, on the following pages I will refer to a field of study in the most inclusive terms. I will refer to it as the theory and philosophy of history that somehow encompasses all the different understandings of "theory", "philosophy", and "history", and I will explain what I think this field of study already is. Not because I wish to reveal the true nature of the theory and philosophy of history, but because it seems to me that the time is ripe for a discussion about what theories and philosophies of history may and may not achieve today, with special attention to the question of how they relate to historical studies.

Nevertheless, there is value in the quick look at the confusion about naming: it attests to the fact that the field of study whose name is in question barely exists institutionally. The field itself is not a subfield of any existing institutionalized discipline, and job openings in "theory of history", "historical theory", or "philosophy of history" are more seldom than heartwarming deeds in Game of Thrones. Individual approaches and projects that constitute a part of the wider field of the theory and philosophy of history are nevertheless hosted by various university departments. History departments at most universities offer methodological courses and courses in historiography (as the study of the history of historical studies) that may optionally include theories in history. A few analytic philosophers can, in principle, maintain an engagement in "philosophy of history" at philosophy departments as one of their focuses. In the last decades, departments of English and (comparative) literature routinely discussed themes that overlap with themes discussed in the theory and philosophy of history (like that of historical narratives). Such thematic overlaps and partial inclusions in educational and research profiles, however, 
do not create a shared sense of institutional or disciplinary integrity; on the contrary, they create institutional division and sometimes even intellectual discord from institutional divisions.

But defying the rigid institutional landscape may not be a bad thing after all, if the theory and philosophy of history can achieve integrity by other means. So is there anything that could create a sense that the theory and philosophy of history may constitute a field of study in the first place? I believe there is. For despite all disagreements about naming (disagreements about questions of inclusion and exclusion) and despite the lack of formal institutional and disciplinary integrity, I think that there are two major centripetal factors that generate a sense that there may be a wider field of study in the most inclusive terms.

The first factor is the ongoing discussion that takes place not only at conferences and workshops, but also in certain common venues. Analytic philosophies of history, philosophical takes on history as the course of human affairs, methodological treatises, histories of history, critical theories of historical work, conceptual works on the notion of history, questions of postcolonial and gender theory in and as history, and several other diverging approaches meet on the pages of journals ranging from History and Theory through Historein, Rethinking History, the Journal of the Philosophy of History and Storia della Storiografia to this very journal. Behind this ongoing discussion lies the second centripetal factor, namely, the informal and quasi-formal networks, centers and hubs. Without aiming at providing a full list, you can think of the most integrative International Network for Theory of History in Ghent, the more focused research seminar in philosophy of history at the Institute of Historical Research in London, the Centre for Philosophical Studies of History in Oulu, the Metahistorias group and research program in Buenos Aires with a history of almost two decades, the Sociedade Brasileira de Teoria e História da Historiografia (Brazilian Society for Theory and History of Historiography) in Brazil with a focus on the history of historiography, or the Zentrum for Theorien in der Historischen Forschung (Center for Theories in Historical Research) recently launched in Bielefeld. 
The pioneering work of a previous generation of eminent scholars may have led to the existence of all this. However, in the first decades of the new century, a younger generation is pulling the diverging threads together and trying to establish common platforms for exchanging ideas about history. These centripetal factors may be accompanying phenomena of a wider reorientation of the field of the theory and philosophy of history, which would hardly be surprising news to any historians. For not only history as historiography changes - of which historians are very well aware (SPIEGEL 2007; HUGHES-WARRINGTON 2013) but its theory and philosophy changes too.

The changes in the theoretical field may or may not interact with historiographical changes. In fact, the overall question of the relationship between the theoretical field and historical work is precisely what is at stake in the wider exchange of ideas about history in the aforementioned common platforms. As soon as you enter the exchange, you take on the scholarly role of a theorist of history, defined by your very engagement in that widely construed exchange. And it is, I believe, the actions emerging from the scholarly role that constitute the field of the theory and philosophy of history, and the field itself is held together by the abovementioned shared platforms and networks of exchange, giving a certain degree of integrity and coherence to an otherwise barely institutionalized field of study. But then, if the formal institutional situation is not decisive, the following question arises: what does it mean to take on the role of a theorist of history? What do you do as a theorist of history? Are you at least expected to develop or hold "a theory of history"? Or, to put it preposterously simply, do theorists of history necessarily have a theory of history?

To answer this question, first I must answer the question about what "a theory of history" might be. As I see it, a theory of history is precisely what it grammatically is: it is a theory; and it is a theory of history. A theory of history is no more the theory of history than Foucault's The History of Sexuality (FOUCAULT 1978-1986) really is the history of sexuality (even 
if hardcore fans of Foucault may treat it as if it really was), while the "of" in the phrase "a theory of history" can be interpreted in two major ways. First, it can mean a theory that belongs to history, in which history is understood only as the discipline. In this sense, a theory of history is a theory internal to or internalized by the practice of history, and the term "theory" is very loosely defined. So loosely that in fact it is not defined at all, usually being regarded as a methodology like Skinnerian intellectual history, an approach like the currently fashionable global history, critical theories as appropriated to historiography like postcolonial theory and postcolonial history, a long-term historical interpretation (like "theories" of modernization or secularization), or any mixture of these and other internal or internalized theories.

Some of these are compatible with each other while some are not. But in principle you have a choice about them, and your choice does not imply a normative statement that would concern the entire discipline. Although there certainly are dominant internal theoretical choices at certain times in certain environments, if you choose to write a microhistory, it simply does not imply that the entirety of historical studies should transform into microhistory. The same way - just to have a timelier example -, if you choose to write a global history, it does not imply that all your colleagues should follow suit and write only global histories from now on, despite all appearances. The particularity of internal theoretical choices is even better illuminated by a combination of such choices. If your global history is also an environmental history that appropriates insights of postcolonial history as informed by postcolonial theory, then you certainly would not think that your internal theories of history should be of universal validity for the entire discipline. Or, to have a concrete example, if you think with Angelika Epple that practice theory may solve some challenges of writing global history (EPPLE 2018), then you definitely would not think that practice theory should be integrated to all historical approaches. Most likely, you would not even think that the adoption of practice theory is a solution for all varieties within that particular historical approach called 
global history. Plainly put, having "a theory of history" in this sense is a matter of particular choices. Although these choices bring about changes within the discipline, they do not change the entire discipline.

The case is very different when considering the second major interpretation of the phrase "a theory of history", meaning a theory about history. Here history can mean both historical studies and the course of human affairs, and a theory about any of them clearly implies a universality claim. What this universality claim means is that a theory of history as a theory about history demands validity concerning all historical practices the discipline consists of (if you talk about history as historical studies), and it demands validity concerning an overall view of the changing world of human affairs (if you are among the few theorists of history who are willing to talk about such things). In the last few decades, theorizing about history dominantly fell into the former category. Although a revival of theorizing history as the changing world of human affairs might very well prove to be the much-needed refreshment in the theory and philosophy of history, for now, "a theory of history" as a theory about history still has the primary focus on historical writing. Such a theory of history (as historiography) explains history on a level so general that is indifferent to the methodological plurality of historical approaches. Notwithstanding the fact that methodological treatises are usually also labeled as "theory", a theory about history explains or understands history (both as historiography and as the changing world of human affairs) regardless of the particular ways historians have or invent to satisfy their particular curiosities (methods), and regardless of the curiosities themselves (specific study subjects).

Just like an internal theory of history, a theory of history in this sense also brings about changes regarding history. But unlike an internal theory of history, its function is not to bring about a change within the discipline. ${ }^{1}$ Instead, it changes the entire discipline by describing and explaining it in a fresh way that sheds a new light on what previously has been thought

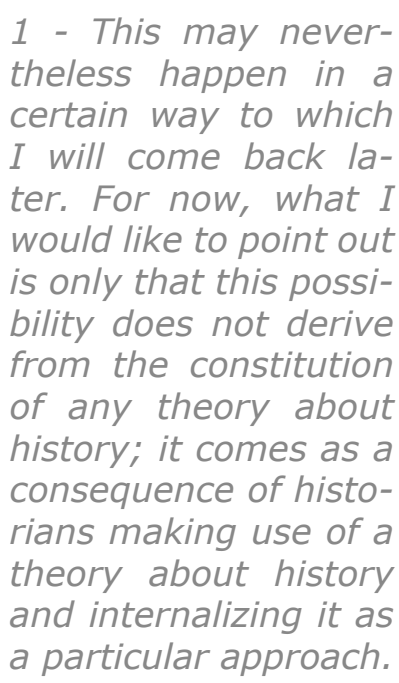
a particular approach. 
about history. The most obvious example here is theoretical work on history as narrative, inspired either by analytic philosophy or the work of Hayden White. Whereas theories that belong to historical studies are responsible for the inner orientation of the discipline, theories about history may change the selfimage of the entire discipline and thus orient the discipline in its outer relation to other disciplines.

The same goes for a theory of history as a theory about history which concerns history as the changing world of human affairs: it may change whatever has been previously thought about historical change by conceptualizing novel ways in which the past, present and future relate to each other. This latter case entails what I think is the most fruitful relationship between theories and philosophies of history and historical studies. Rather than merely discussing the work of the discipline of history, theories of history can, in principle, work together with historical studies on developing ways to understand the historical condition of ourselves and the world. Not instead of theorizing the work of historical studies but supplementing it; and not in a way that revives classical philosophies of history as large-scale interpretations of an overall historical process, but in novel ways that evade the much-criticized presuppositions of those philosophies of history, such as teleology, ultimate meaning, or linear temporality.

The old-fashioned distinctions between "critical" and "speculative" or "analytical" and "substantive" philosophy of history are, in fact, already overwritten today in a variety of ways. The case is not that the distinctions merely lost their appeal; what occurs is that the categories of these distinctions cannot adequately capture the character of much of recent theoretical work on history. To one extent or another, they simply do not apply to a vast amount of work on historical time (as recently reviewed by FARELD 2016) and related topics such as periodization and chronology (LORENZ 2017; JORDHEIM 2019); to François Hartog's analysis of "regimes of historicity" (HARTOG 2015); to Berber Bevernage's call for a philosophy 
of historicity (BEVERNAGE 2012); to Eelco Runia's philosophy of history (RUNIA 2014); to Dipesh Chakrabarty's efforts to understand the historicity brought forth by the Anthropocene predicament (CHAKRABARTY 2009; 2018); and hopefully to my half-decade work on "unprecedented change" as a novel kind of historical change (culminating in SIMON 2019). Instead of being "analytical" and "critical" or "speculative" and substantive" philosophies of history, all these theories wish to explore an entire historical condition, which provides a shared object of study with historical studies on the one hand and implies a theory of historical studies on the other (by virtue of the fact that the discipline of history necessarily operates under the historical condition explored by these theories).

Now, why does it seem to be important to point all this out? First, because we witnessed a theoretical excess in the last decades without substantially reflecting upon what theory might be able to achieve, or more precisely, without discussing which notion of theory could achieve what. Second, because a recent collaborative intervention of the Wild On Collective (Ethan Kleinberg, Joan Scott, and Gary Wilder) - an online manifesto entitled Theses on Theory and History - intends to rekindle debates on the theoretical conduct of historical studies, or the lack thereof (WILD ON COLLECTIVE 2018).

The ideas at the core of theoretical debates in the last halfcentury were ideas of "a theory of history" that tried to explain the entirety of historical studies. Yet they were often conflated with (at best) and mistaken for (at worst) internal theories of history and expected to transform the practice of historical studies. "Postmodern" theories of history were especially prone to such expectations. Both its advocates and opponents thought that the measure of success of such overall theories must be their ability to bring about a spectacular change not merely by describing and explaining the entire discipline in a fresh way but also by applying its insights. As Ernst Breisach put it, their success seemed to depend on "whether life would conform or could be made to conform to theoretical expectations" (BREISACH 2003, p. 202). 
But such thing simply could not have happened. For how could a theory that explains the entirety of historiography require any practical conformation to its terms on behalf of historiography if what such a theory claims is precisely what historiography already is as theory describes it? No particular history can conform to a universal theoretical notion such as the notion of non-referential language. If you subscribe to a theory of history that advocates such a view on language, you already consider every history ever written since the institutionalization of historical studies as having a non-referential language. How could you expect a transformation of historical practice to result in non-referential written histories if you think that all written histories are non-referential anyways? To have a concrete example in the shape of postmodern calls for such overall transformations, ${ }^{2}$ when Munslow defined "written history as a socially constituted narrative representation that recognizes the ultimate failure of that narrative form to represent either accurately or objectively" (MUNSLOW 1997, p. 17), then all histories ever written and all histories yet to be written should have appeared to him as so. And if written history is already so, then the imperative of turning it into that which it already is amounts to an unintelligible enterprise. Paternalizing historical practice by demanding conformation to overall theoretical definitions of historical studies only creates rifts between historical studies and theories about history, despite the fact that it simply makes no difference whether historians accept the overall definition or not. From the viewpoint of such a theory, history will be as the definition claims, regardless of what historians think about it.

It is nevertheless possible to be inspired by such theories about history, just as much as by any other theory. To begin with, consider the way Quentin Skinner internalized speech act theory (SKINNER 2002). Skinner turned to universal philosophical notions about language, that is, to notions that describe language use without temporal and spatial confines. What Wittgenstein said about language and meaning, and what J. L. Austin said about the performative function of language,

2 - For a relatively late call see BOWEN RADDEKER, 2007. For an earlier one see JENKINS 1991. 
Skinner took as being valid concerning a subcase of the general case: the language in which his sources has been written. In doing so, Skinner construed a subject of study that intended to explore what certain political theorists had been doing through writing political theories (that is, through their performative speech acts), and he devised a method that he thought was best suited for studying the subject in question. In other words, Skinner took a theory demanding universality regarding all speech acts regardless of temporal and spatial confines, and turned its insights into an internal theory of history, as a method in the history of ideas.

On the same premise, even a theory about history can be internalized (thus becoming a particular approach among the many existing ones), and if it takes root, it may result in changes within the discipline. This is precisely what Ann Rigney did in mapping various narrative representations of the French Revolution (RIGNEY 1990), or what experimental histories did in exploring new ways of writing history and new representational forms inspired by narrativist insights (MUNSLOW; ROSENSTONE 2004). Yet, as Frank Ankersmit pointed out, each experiment, if it wishes to qualify as experimental, must be unique even when compared to other experiments. Even if taken together they may qualify as a "specific class" of historical studies, to remain experimental they need other forms of historical studies to differ from (ANKERSMIT 2007, p. 181). Explained in the terms of this essay, experimental history may bring about particular changes within historical studies by internalizing and particularizing a general theory about history, but only as an internalized theory of history and not as a theory about history.

These are then, I think, the two major senses of "a theory of history": a theory that belongs to history as historical studies and constitutes a specific method or approach, and a theory about the entirety of history understood either as historical studies or the changing world of human affairs (or a theory about both). ${ }^{3}$ Acting in the role of a theorist of history might

\begin{abstract}
3 - It is also possible to say that internal theories of history are theories in history as opposed to theories of history which are about history. This is how, in negotiating the character of events organized by the Zentrum in Bielefeld, we often distinguished between them. Yet, when the aim is to achieve the integrity of the theory and philosophy of history as an inclusive field of study, the "in" and "of" introduces yet another unnecessary division that could easily be turned into means of separating theoretical work concerning history into two rigid fields. For this reason, I would keep on arguing for a shared sense of "a theory of history" that consists of two occasionally intertwining subcases, referring to internal theories of history and theories about the entirety of history.
\end{abstract}


result in developing "a theory of history" of either type, as Skinner's and Munslow's examples show. And as the case of experimental history indicates, these two senses of "a theory of history" may even interact. But the main point I would like to make is that acting in the role of a theorist of history means committing - either explicitly or implicitly - to "a theory of history" in one sense or the other. This of course does not mean that theorists of history necessarily develop a full-blown theory, be it a Skinnerian method or a postmodern theory of history. It only means that insofar as theorists of history enter the exchange of ideas, they at least presuppose one, contribute to one, or argue in favor or against one. For "a theory of history" is simply the purpose of the game. The most important thing to keep in mind when entering the exchange is not to confuse the expectations attached to one or the other sense of "a theory of history", like it constantly happened throughout the last decades.

Now that the heyday of narrative philosophy of history and postmodern theory of history is over, now that a younger generation takes on the role of theorizing history against the backdrop of the experiential horizon of their own times, now that networks, centers, and hubs try to pull together the widely understood field of the theory and philosophy of history, the time is ripe for coming to terms with the question of what can reasonably be expected of what sort of "theory of history". If, as I think, Ewa Domaska is right that today we need to develop theories of history adequate to address the global problems of our own times (DOMANSKA 2010), then it is equally important to have an idea of what such theories may be good for. This could be the first step towards a more fruitful relationship between the non-discipline of the theory and philosophy of history and the institutionalized disciplines whose paths it crosses, especially that of history. For the theory and philosophy of history is more than a collection of inherited concerns with the oftentimes mistaken ambitions of the last half-century. Today, it is what we are about to make out of it. 


\section{REFERÊNCIAS BIBLIOGRÁFICAS}

ANKERSMIT, Frank. Manifesto for an Analytical Political History. In: JENKINS, Keith; MORGAN, Sue; MUNSLOW, Alun (eds.). Manifestos for History. London and New York: Routledge, p. 179-196, 2007.

BEVERNAGE, Berber. From Philosophy of History to Philosophy of Historicities: Some Ideas on a Potential Future of Historical Theory. BMGN - Low Countries Historical Review, v. 127, n. 4, p. 113-120, 2012.

BOWEN RADDEKER, Hélène. Sceptical History: Feminist and Postmodern Approaches in Practice. London and New York: Routledge, 2007.

BREISACH, Ernst. On the Future of History: The Postmodernist Challenge and its Aftermath. Chicago: The University of Chicago Press, 2003.

CHAKRABARTY, Dipesh. The Climate of History: Four Theses. Critical Inquiry, v. 35, n. 2, p. 197-222, 2009.

Anthropocene Time. History and Theory, v. 57, n. 1, p. 5-32, 2018.

DANTO, Arthur C. Narration and Knowledge: Including the Integral Text of Analytical Philosophy of History. New York: Columbia University Press, 1985.

DOMANSKA, Ewa. Beyond Anthropocentrism in Historical Studies. Historein, v. 10, p. 118-130, 2010.

FARELD, Victoria. (In) Between the Living and the Dead: New Perspectives on Time in History. History Compass, v. 14, n. 9, p. $430-440,2016$. 
HUGHES-WARRINGTON, Marnie. Revisionist Histories. London and New York: Routledge, 2013.

JENKINS, Keith. Rethinking History. London and New York: Routledge, 1991.

JORDHEIM, Helge. Return to Chronology. In: TAMM, Marek; OLIVIER, Laurent (eds.). Rethinking Historical Time: New Approaches to Presentism. London: Bloomsbury, 2019. Forthcoming.

LORENZ, Chris. "The Times They Are a-Changin": On Time, Space and Periodization in History. In: CARRETERO, Maria; BERGER, Stefan; GREVER, Maria (eds.), Palgrave Handbook of Research in Historical Culture and Education. Palgrave, p. 109-131, 2017.

FOUCAULT, Michel. The History of Sexuality. 3. Vols. New York: Pantheon, 1978-1986.

HARTOG, François. Regimes of Historicity: Presentism and Experiences of Time. New York: Columbia University Press, 2015.

EPPLE, Angelika. Calling for a Practice Turn in Global History: Practices as Drivers of Globalization/s. History and Theory, v. 57, n. 3, p. 390-407, 2018.

MUNSLOW, Alun. Deconstructing History. London and New York: Routledge, 1997.

MUNSLOW, Alun; ROSENSTONE, Robert A. (eds.). Experiments in Rethinking History. London and New York: Routledge, 2004.

PARTNER, Nancy. Foundations: Theoretical Framework for Knowledge of the Past. In: PARTNER, Nancy; FOOT, Sarah (Eds.). The SAGE Handbook of Historical Theory. LOS Angeles: SAGE, 2013, p. 1-8. 
PAUL, Herman. Key Issues in Historical Theory. London and New York: Routledge, 2015.

RIGNEY, Ann. The Rhetoric of Historical Representation: Three Narrative Histories of the French Revolution. Cambridge: Cambridge University Press, 1990.

RUNIA, Eelco. Moved by the Past: Discontinuity and Historical Mutation. New York: Columbia University Press, 2014.

SIMON, Zoltán Boldizsár. History in Times of Unprecedented Change: A Theory for the 21st Century. London: Bloomsbury, 2019. Forthcoming.

SIMON, Zoltán Boldizsár; KUUKKANEN, Jouni-Matti. Introduction: Assessing Narrativism. History and Theory, v. 54, n. 2, p. 153-161, 2015.

SKINNER, Quentin. Visions of Politics Vol. 1: Regarding Method. Cambridge: Cambridge University Press, 2002.

SPIEGEL, Gabrielle M. Revising the Past / Revisiting the Present: How Change Happens in Historiography. History and Theory, v. 46, n. 4, p. 1-19, 2007.

WALSH, William H. Philosophy of History: An Introduction. New York: Harper, 1960.

WILD ON COLLECTIVE. Theses on Theory and History. 2018. Available at: http://theoryrevolt.com/. Accessed in: feb. 28, 2019.

\section{AGRADECIMENTOS E INFORMAÇŌES}

\section{Zoltán Boldizsár Simon}

zoltanbsimon@uni-bielefeld.de

Bielefeld University - Germany 